\title{
Knowledge, Attitudes, Behavior And Risk Assessment Of People In Bulukumba Regency During The COVID 19 Pandemic
}

\author{
Safruddin 1, Asri $^{2 *}$, Edison Siringoringo 3 \\ Departemen Keperawatan Komunitas, Stikes Panrita Husada Bulukumba,Indonesia 1,2,3, \\ ${ }^{*}$ Corresponding Autor: asriiffat@gmail.com
}

\begin{abstract}
ABSTRAK
Coronavirus (COVID-19) is a serious health problem in the world at the end of 2019. The World Health Organization (WHO) states that COVID-19 disease is categorized as a global pandemic. The Indonesian government is making various efforts to improve the handling of COVID-19, to control the transmission of COVID-19 by conducting mass screening, social restrictions and selfquarantine. COVID-19 countermeasures continue to this day, community compliance is needed to the efforts taken, which are largely influenced by people's knowledge, attitudes, and actions towards COVID-19. The purpose of this research is to know the picture of knowledge, attitudes, behavior and assessment of community risks in Bulukumba Regency during the Covid 19 Pandemic. This research method uses quantitative methods with the number of samples are the people in Bulukumba Regency as many as 725 people. Sampling techniques using cluster random sampling. The results of the analysis of univariate data obtained by some people have knowledge during the COVID-19 pandemic is well informed, which is a number of 336 people 46.3\%), most of the attitudes of the community during the COVID-19 Pandemic are positive attitudes which amount to 356 people (49.1\%), some people's behavior during the COVID-19 Pandemic is a good action of 304 people (41.9\%). And the moderate risk assessment was 359 people (49.5\%). Some people in Bulukumba Regency have good knowledge, positive attitudes and good behavior and moderate risk assessment in an effort to prevent the occurrence of COVID-19 transmission.
\end{abstract}

Keywords; Knowledge, Attitudes, Behavior, Risk Assessment

\section{INTRODUCTION}

Coronavirus disease is a serious health problem in the world at the end of 2019. Coronavirus 2019 (COVID-19) is the first respiratory infection manifested by a mysterious group of pneumonias in Wuhan, capital of Hubei Province, China.(Lake, 2020; X. Bo et al, 2020). The disease is designated by the World Health Organization (WHO) under the name COVID-19. COVID-19 caused by SARS-COV2 which belongs to the same large family of coronaviruses that caused SARS in 2003, only different types of viruses.(Kementerian Kesehatan RI, 2020). This disease has typical symptoms if it infects humans. Some typical symptoms caused by COVID-19 virus infection such as fever, dry cough, dyspnea, headache, and pneumonia, which usually develop after incubation time for 2 weeks (Kemkes, 2020). In severe cases characterized by acute 
respiratory distress syndrome, septic shock, difficult-to-treat metabolic acidosis, bleeding dysfunction and coagulation (Cuiyan Wang, 2020), This disease is considered very dangerous by who.

The number of cases of coronavirus infection in the world continues to increase so that the World Health Organization (WHO) states that the coronavirus is categorized as a global pandemic (WHO, 2020). Until Tuesday (31/3/2020) morning Worldometer, March 31, 2020, stated that 204 countries / regions have been infected with the coronavirus. The number of coronavirus cases worldwide has reached 789,737 cases, cured as many as 166,730 people, died as many as 38,100 people. The spread of cashiers also occurred in Indonesia Indonesia is one of the countries affected by the COVID-19 outbreak. COVID-19 is very fast spreading, until March 31, 2020, the number of positive COVID-19 in Indonesia as many as 1,528 cases, patients recovered 81 people, died as many as 136 people (Kementerian Kesehatan RI, 2020). Sehingga pemerintah Indonesia dengan cepat melakukan berbagai upaya untuk mengendalikan penyakit tersebut.

The Indonesian government is making various efforts to improve the handling of COVID-19, to control the transmission of COVID-19 by conducting mass screening, conducting social restrictions and self-quarantine involving government, local governments, and communities including businesses, people only staying at home, studying, working and doing activities at home to avoid contact with others. Restrictions on public transport and flights and quarantine and health observation of people newly exposed to infected areas, closure of public places, prohibition of mass gathering activities, isolation and intensive care for people suspected of being infected with COVID-19(Kompas. com, 2020).

This continues to be done to maintain transmission. Efforts to counter Covid 19 in Bulukumba Regency by forming a task force to accelerate the response to Covid 19. The first case of Covid-19 in Bulukumba Regency on March 25, 2020 and until July 2020 has reached 224 people where patients recovered have reached 145 people with the death toll of 5 people. (Hendrawan, 2020). COVID-19 countermeasures continue to this day. To ensure that countermeasures continue, community compliance is needed to the measures taken, which are largely influenced by the knowledge, attitudes, and actions of the community towards COVID-19. According to (Aritonang, 2015), Knowledge is influenced by a person's experience and environment which can then be expressed and 
believed to bulk up motivation. According to (Moudy \& Syakura, 2020), employment and educational background / employment with knowledge level of COVID-19. Knowledge of COVID-19 patients can be interpreted as the result of knowing from the patient about the disease, understanding the disease, prevention, treatment and complications.(N. Mona, 2020). According to (Moudy \& Syakura, 2020), People's attitude towards COVID-19 gives a positive attitude towards COVID-19 disease, namely by being careful and increasing its efforts in maintaining health. So that unwanted risk can be reduced.

\section{METHODS}

This research method is a study with quantitative methods used to find out the picture of knowledge, attitudes, behavior and assessment of the risks of the people of Bulukumba Regency during COVID-19. The population is the people of Bulukumba Regency. The sample was the people of Bulukumba Regency as many as 725 people. Sampling techniques using cluster random sampling. Study data was collected from online questionnaires distributed through whatApp communication media in April - May 2020. The data was collected using a closed question questionnaire. The questionnaire contains questions used to obtain data or information related to socio-demographics, knowledge, attitudes and actions of the community during the COVID-19 pandemic. Knowledge is assessed using 15 closed question items. Attitudes were assessed with 12 statement items and 13 behaviors with question items as well as Personal Risk assessments with 21 statement items. The data analysis used is univariate with frequency distribution.

\section{RESULTS AND DISCUSSIONS}

The results of this study will explain the characteristics of respondents about COVID-19 transmission and analysis of univariate data is carried out to find out the picture of the distribution of variable frequencies of knowledge, attitudes, behavior and risk assessment of people in Bulukumba Regency during the COVID-19 pandemic. 
Table 1. Characteristics of respondents about covid 19 communities in Bulukumba Regency during the COVID-19 pandemic.

\begin{tabular}{llll}
\hline & Characteristic & Frequency & Percentage \\
\hline Gender & Male & 434 & 59.9 \\
& Female & 291 & 40.1 \\
Eevel Of & Not School & 28 & 3.9 \\
& & 174 & 24.0 \\
& SD & 159 & 21.9 \\
& Junior high school & 223 & 30.8 \\
& Senior High School & 133 & 18.3 \\
& College & 8 & 1.1 \\
& Student & 149 & 20.6 \\
Profession & IRT & 453 & 62.5 \\
& Work & 80 & 11.0 \\
\hline Total & Student & 43 & 5.9 \\
\hline
\end{tabular}

The table showed that respondents with a male gender of 434 people (59.9\%) more than women who numbered 291 people (40.1\%). The most high school educated respondents with 223 people (30.8\%) and the fewest students were 8 (1.1\%) students. The most employed respondents were 453 (62.5\%) and the least worked with 43 (5.9\%).

Table 2. Knowledge , attitudes, behavior, risk assessments about COVID-19 in Bulukumba Regency during the COVID-19 pandemic

\begin{tabular}{llll}
\hline & Characteristic & Frequency & Percentage \\
\cline { 1 - 3 } Knowledge & Good & 336 & 46.3 \\
& Not Good & 389 & 53.7 \\
Attitudes & positif & 356 & 49.1 \\
& Negatif & 369 & 50.9 \\
Behavior & Good & 304 & 41.9 \\
\hline
\end{tabular}




\begin{tabular}{llll}
\hline \multirow{2}{*}{ Risk Assessment } & Not Good & 421 & 58.1 \\
& Low Risk & 329 & 45.4 \\
& Medium Risk & 359 & 49.5 \\
& High Risk & 37 & 5.1 \\
\hline Total & & $\mathbf{7 2 5}$ & 100 \\
\hline
\end{tabular}

The results showed that from the overall respondents obtained data with good knowledge with a total of 336 people (46.3\%) less than less knowledge with the number of 389 people (53.7\%) in the people of Bulukumba Regency during the COVID-19 pandemic. Respondents' attitudes were more negative with 369 people (50.9\%) compared to 356 positive people (49.1\%) in bulukumba regency during the COVID-19 pandemic. More people's behavior is less with the number of 421 people (58.1\%) compared to good behavior with the number of 304 people (41.9\%) in the community of Bulukumba Regency during the COVID-19 pandemic and the risk assessment of respondents is most moderate risk with the number of 359 people (49.5\%) compared to the low risk with the number of 329 people (45.4\%) and the high risk with the number of 37 people (5.1\%) in the community of Bulukumba Regency during the COVID-19 pandemic.

\section{DISCUSSION}

\section{Public knowledge during the COVID-19 pandemic}

In this study it was found that knowledge in the community of Bulukumba Regency during the COVID-19 pandemic with a greater proportion of knowledge (53.7\%) compared to good knowledge. (46,3\%). The results of this study contradict the study.(Sitohang et al., 2021) That good knowledge is a number (71.1\%), the results of this study also contradict the research conducted (Wulandari et al., 2020), That the majority of the public has a good knowledge (69.2\%) about the prevention of COVID-19. The results of this study also contradict the research (Devi Pramita Sari and Nabila Sholihah 'Atiqoh, 2020). That public knowledge about COVID-19 is a good majority of $69.35 \%$. The difference is because it is due to the characteristics of the response in this study to the people who became the most respondents to high school education (30.8\%).

Knowledge of COVID-19 disease is very important to prevent an increase in the number of cases of COVID-19 disease. A person's knowledge of COVID-19 can be 
interpreted as the result of knowing from a person about COVID-19 disease, understanding COVID-19 disease, how to prevent, treat and complications of COVID-19 disease (N. Mona, 2020)

According to (Aritonang, 2015) Knowledge is influenced by a person's experience and environment which can then be expressed and believed to give rise to motivation. Based on the researchers' analysis, most of the people of Bulukumba Regency during the COVID-19 pandemic have a good knowledge of COVID-19 which is as much as (46.3\%) can be caused by the lack of information services available to the public about COVID-19 disease, including epidemiology, causes, transmission, signs and symptoms, prevention, management and management of COVID-19 disease, which can be accessed by the public from various information media sources.

According to the researchers' analysis, most of the people of Bulukumba Regency have good knowledge during the COVID-19 pandemic can be caused by the activeness of the community to find sources of information to get knowledge about COVID-19 disease and how to prevent COVID-19. In addition to this, most of the people of Bulukumba Regency can also be influenced by the background of work and education of the people of Bulukumba Regency.

\section{People's attitudes during the COVID-19 pandemic}

The results showed that the attitude of more respondents was negative $50.9 \%$ compared to the positive $49.1 \%$ in the people of Bulukumba regency. The results are different from studies in China that showed that the majority of the Chinese population (97.1\%) have a positive attitude by having the confidence to win the fight against COVID-1.(Zhong et al., 2020). This is due to differences in the research area and the characteristics of the respondents. According to (Notoadmojo, 2020) An attitude is the reaction or reaction of a person or person to a stimulus or object that is still closed. The performance of this attitude cannot be directly seen, but can only be explained directly from closed behavior. Attitudes have not been behaviors or activities, but are a tendency toward behavior. Attitudes are still closed responses, not open responses or open behaviors.

Attitude is the preparation for responding to an object in a particular environment, i.e. appreciation of the object. Attitudes are the opinions or judgments of people or respondents about health-related issues, health diseases and health risk factors. This research contradicts the research conducted.(Sitohang et al., 2021) Most western 
Indonesians have good knowledge, a positive attitude and positive actions in an effort to prevent the transmission of COVID-19.

This is similar to the theory stated by Mednick, Higgins and Kirschenbaum that attitude formation is influenced by three factors, namely social influences such as norms and cultures, personality character of individuals, and information that has been received by the individual (Aritonang, 2015). Attitudes are categorized positively towards the prevention of COVID-19 if individuals have a calm, careful attitude and improve efforts to maintain health to avoid COVID-19 disease (Moudy \& Syakura, 2020). Some people in Bulukumba Regency have almost the same attitude between being positive and negative because this survey was conducted at the beginning of the pandemic period where information is still lacking so that public opinion or assessment related to COVID-19 is still low.

\section{People's behavior during the COVID-19 pandemic}

In this study it was also obtained that most of the behavior of the people of Bulukumba Regency during the COVID-19 Pandemic was good behavior which amounted to 304 people (41.9\%). Where people who wear masks when leaving the house by $62.2 \%$. People who wash their hands with soap after arriving home by $61.7 \%$ and people who keep a distance of 1.5 meters with others when shopping, working, studying, worship by $56.3 \%$. The results of this study are in line with the research.(Moudy \& Syakura, 2020) The majority of respondents washed their hands with water and soap (92.2\%), wore masks when coughing /colds (83.5\%), and covered their mouth and nose using tissue when sneezing or coughing $(79.8 \%)$. The results of this study are also in accordance with research conducted in Chinese society. In the study, almost all respondents used masks when going out (98\%), and did not visit crowds (96.4\%). (Zhong et al., 2020).

While survey results (Badan Pusat Statistik RI, 2020) In September 2020 it showed that people's compliance rate of wearing masks (91.98\%), washing hands (75.38\%) and keeping a distance of 73.54\%. Based on the above data, it can be judged that most of the people in Bulukumba Regency at the beginning of the COVID-19 pandemic have made efforts to prevent the transmission of COVID-19 even though it has not reached its maximum.

\section{Community risk assessment during the COVID-19 pandemic}

Risk assessment in the community in Bulukumba Regency is most moderate risk 
with a total of 359 people (49.5\%) compared to low risk with 329 people (45.4\%) and high risk with 37 people (5.1\%) in bulukumba regency during the Covid 19 pandemic. This shows that the risk is still dominant moderate and low, although it still needs maximum efforts to prevent the risk of contracting because COVID-19 has very high transmission.

\section{CONCLUSION}

The results of this study showed that most of the knowledge of the people of Bulukumba Regency during the COVID-19 pandemic was well-informed, which is $46.3 \%$, most of the attitudes of the people of Bulukumba Regency during the COVID-19 Pandemic were positive attitudes of $49.1 \%$, most of the actions of the people of Bulukumba Regency during the COVID-19 Pandemic were good behavior of 41.9\%. Most of the people of Bulukumba Regency have good knowledge, a positive attitude and positive actions in an effort to prevent the transmission of COVID-19.

\section{REFERENCES}

Aritonang, T. R. (2015) 'Hubungan Pengetahuan Dan Sikap Tentang Kesehatan Reproduksi Dengan Perilaku Seks Pranikah Pada Remaja Usia (15-17 Tahun) Di SMK Yadika 13 Tambun, Bekasi', 3, p. 7.

Badan Pusat Statistik RI (2020) Perilaku MasyarakatdiMasa Pandemi Covid-19. Hasil Survey 7 - 14 September 2020.

Cuiyan Wang (2020) 'Immediate Psychological Responses and Associated Factors during the Initial Stage of the 2019 Coronavirus Disease (COVID-19) Epidemic among the General Population in China'.

Devi Pramita Sari and Nabila Sholihah 'Atiqoh (2020) 'Hubungan Antara Pengetahuan Masyarakat Dengan Kepatuhan Penggunaan Masker Sebagai Upaya Pencegahan Penyakit Covid-19 Di Ngronggah', Infokes: Jurnal IImiah Rekam Medis dan Informatika Kesehatan, 10(1), pp. 52-55. doi: 10.47701/infokes.v10i1.850.

Hendrawan, E. (2020) 'Bertambah 23, Positif COVID-19 di Bulukumba Tembus 224 Kasus', Berita Sindonews Makassar, 20 July.

Kementerian Kesehatan RI (2020) 'Direktorat Jenderal Pencegahan dan Pengendalian Penyakit (P2P). Pedoman Pencegahan dan Pengendalian Coronavirus Disesase (Covid-19). Jakarta

Kompas. com (2020) Update Virus Corona. 
Lake, M. A. (2020) 'What we know so far: COVID-19 current clinical knowledge and research', Clinical Medicine, 20(2), pp. 124-127. doi: 10.7861/clinmed.2019-coron.

Moudy \& Syakura (2020) 'Pengetahuan terkait Usaha Pencegahan Coronavirus Disease (COVID-19) di Indonesia', Higeia Journal Of Public Health Research And Development, 4(3).

N. Mona (2020) 'Konsep Isolasi Dalam Jaringan Sosial Untuk Meminimalisasi Efek Contagious (Kasus Penyebaran Virus Corona Di Indonesia)', Jurnal Sosial Humaniora Terapan, 2(2), pp. 117-123.

Notoadmojo, S. (2020) Pendidikan dan Perilaku Kesehatan. Rineka Cipta.

Sitohang, T. R. et al. (2021) 'PERILAKU MASYARAKAT INDONESIA BAGIAN BARAT SELAMA PANDEMI COVID 19', Jurnal Kesehatan, 11(3), p. 356. doi: 10.35730/jk.v11i3.775.

WHO (2020) Coronavirus disease 2019 (COVID-19). Geneva, Switzerland.

Wulandari, A. et al. (2020) 'Hubungan Karakteristik Individu dengan Pengetahuan tentang Pencegahan Coronavirus Disease 2019 pada Masyarakat di Kalimantan Selatan', Jurnal Kesehatan Masyarakat Indonesia, 15(1), p. 42. doi: 10.26714/jkmi.15.1.2020.42-46.

X. Bo et al (2020) 'Epidemiological data from the case information', Sci. data, 7.

Zhong, B.-L. et al. (2020) 'Knowledge, attitudes, and practices towards COVID-19 among Chinese residents during the rapid rise period of the COVID-19 outbreak: a quick online cross-sectional survey', International Journal of Biological Sciences, 16(10), pp. 1745-1752. doi: 10.7150/ijbs.45221. 